\title{
An Argument from Silence: The Differing Evidence in the Syriac and Georgian Language Sources
}

\author{
The Evidence from Syria: References to Kartvelians in the Syriac \\ Sources and in the Vitae of Syrian Saints
}

In his account of the life of his acquaintance Symeon Stylites the Elder, Theodoret of Cyrrhus lists the countries of origin of all those who came to visit the saint on his column at Qal'at Sem'an on the Syrian Limestone Massif between Antioch and Beroea (Aleppo) saying:

Not only do the inhabitants of our part of the world flock together, but also Ishmaelites, Persians, Armenians subject to them, Iberians, Homerites, and men even more distant than these; and there came many inhabitants of the extreme west, Spaniards, Britons, and the Gauls who live between them. ${ }^{1}$

This passage is often used as evidence for the relationship between the Iberians and the Syrians in the fifth century, along with passages from the vitae of Symeon the Younger and his mother Martha that were written a century later. ${ }^{2}$ From this it would perhaps appear that there was regular communication between the two regions that was attested to by the literary sources but, as with all the other evidence examined thus far, this promising beginning is deceiving; there are no other clear references to Iberians found in the early Syriac literature and they do not appear to have played a significant role in the development of Syrian Christianity in general or monasticism in particular.

Naturally the argument has been used that since the (As)Syrian Fathers left their homelands to travel to Kartli then there is less likely to be a reference to

1 XXVI, 11, p. 165, Theodoret of Cyrrhus, Trans. Price, R.M., A History of the Monks of Syria, Cistercian Publications; Kalamazoo, 1985.

2 Chapters 103, 130, 131, 136 and 253 of the vita of Symeon and chapters 53, 54, 56, 57 and 65 of the vita of St. Martha concern Iberians. See Van den Ven, Paul, La vie ancienne de S. Syméon Stylite le Jeune (521-592), I. Introduction et texte grec, II. Traduction et Commentaire, Vie grecque de sainte Marie, mère de S. Syméon, Indices, Subsidia Hagiographica 32, Société des Bollandistes; Brussels, 1962 \& 1970.

(C) EMMA LOOSLEY LEEMING, 2018 | DOI:10.1163/9789004375314_009

This is an open access chapter distributed under the terms of the prevailing CC-BY-NC License at the time of publication. 
them in the lands that they left behind and this view obviously has some logic. However, if there was a long established relationship between the two regions then one would expect there to be some reference to this relationship in the Syriac literature. It would be reasonable to expect references to missionaries setting out for the north, for example, or for tales of Syrians who had achieved great feats in the Caucasus, given that the evangelisation of this nation appears to have been widely circulated by Rufinus from approximately the turn of the fourth and fifth centuries onwards. Whilst not extensively known to most outsiders, Kartli was far from being terra incognita and yet there appears to have been no mention of Iberians apart from Theodoret's statement above.

It could also be suggested that we should consider the Greek sources from Syria as well, since the vitae of Symeon the Younger and Martha survive in that language, but this would be overlooking a significant doctrinal issue; the prevailing narrative amongst Georgian scholars for the past century ${ }^{3}$ is that these Fathers were anti Chalcedonian monks fleeing persecution in their homeland. As such they would probably have exclusively used Syriac — a point recognised by both Kekelidze and Aleksidze who refer to this as being the language used by these holy men - because Greek, as the language of their doctrinal and theological opponents, would not have been their language of choice and even if they had been educated in that tongue they are likely to have shunned it for political reasons.

\section{Kekelidze and the Georgian Historiographical Literature on the 'Asirieli Mamebi'}

This brings us to another anomaly, which is the reference to Iberian monks gathering around Symeon the Younger in the sixth century. Symeon the Younger was a known supporter of the Council of Chalcedon and we can be surer of his opinions than those of Symeon the Elder, who died in 459, only eight years after the Council was held in 451. The presence of Iberian monks at his monastery in the sixth century is at odds with the contention that the (As)Syrian Fathers were monophysite. In fact the presence of Iberians makes most sense if we posit the hypothesis that the monks who gathered around Symeon

3 See for example Aleksidze, Zaza, 'Mandilioni da keramioni dzvel kartul mtserlobashi', Academia 1 (2001), pp. 9-15, Kekelidze, Korneli, 'Sakitkhi siriel moghvatseta kartulshi moslvis shesakheb (kulturul-istoriuli problema)', Tplisis universitetis moambe 6 (1925), pp. 82-107, Kekelidze, Korneli, 'Sakitkhi siriel moghvatseta kartulshi moslvis shesakheb (kulturul-istoriuli problema) II', Etyudy 1 (1956), pp. 19-50. 
were rebel Chalcedonian monks who had fled Kartli precisely because they were suffering persecution under the monophysites as the Kartvelian Church was officially still in union with the (non-Chalcedonian) Armenian Church in this century.

However this explanation is complicated by the metaphrastic vita of Shio Mghvimeli that states that Ioane Zedazneli "ascended to the great luminary Symeon of the Admirable Mountain ... who blessed Ioane and his disciples and they prayed before following the road to Kartli." ${ }^{4}$ In fact in his discussion of the (As)Syrian Fathers Kekelidze goes so far as to posit that the terminus ante quem of the arrival of the group who accompanied Ioane Zedazneli must be 541 . This is because Shio's vita explicitly states that the visit occurred in the period when Symeon was residing in an oven in the years immediately before he ascended his column and Kekelidze dates this event to $541 .{ }^{5}$ The complications arise because Kekelidze is adamant that these figures were non-Chalcedonian ${ }^{6}$ when the later written evidence suggests that they were more in sympathy with Chalcedonian thought - something that he himself acknowledges when he later comments that the texts were written in a Chalcedonian context and do not 'reflect reality.7 Therefore on the one hand he uses the sources to date the arrival of Ioane Zedazneli in Kartli and on the other he dismisses them as being at least partially falsified by a later era. This ambivalent attitude is reflected in the fact that although Kekelidze acknowledges that these figures spoke Syriac (or Assyrian as it is referred to in the Georgian texts) he uses references to their purported knowledge of Kartvelian to come to the somewhat startling conclusion that these men were not (As)Syrian, but actually ethnic Kartvelians who were returning to their homeland. As evidence for this Kekelidze cites the meeting of Ioane Zedazneli with Catholicos Evlavi (532-544) as being conducted in Kartvelian. He states that this was perceived as a miracle, but was in fact that this was 'no more no less than Kartvelians speaking Kartvelian to each other.' ${ }^{8} \mathrm{He}$ underlines this argument by commenting that the vitae refer to both Shio Mghvimeli and Abibos Nekreseli studying 'Assyrian', Greek and Kartvelian. However the argument that neither would have needed

4 Translation author's own from p. 103, Kekelidze, Korneli, 'Sakitkhi siriel moghvatseta kartulshi'.

5 pp. 99-10o, Kekelidze, Korneli, 'Sakitkhi siriel moghvatseta kartulshi'.

6 For example he says that the vita of Davit Garejeli has him turn back from Jerusalem because he was unable to enter due to his monophysitism, p. 99, Kekelidze, Korneli, 'Sakitkhi siriel moghvatseta kartulshi'.

7 p. 103, Kekelidze, Korneli, 'Sakitkhi siriel moghvatseta kartulshi'.

8 pp. 103-104, Kekelidze, Korneli, 'Sakitkhi siriel moghvatseta kartulshi'. 
to study the 'Assyrian' language if he were already of (As)Syrian origin is weakened by the reference to fact that they both reportedly also studied Kartvelian as well and by this logic it would have been uneccessary to study Kartvelian if that was their native language. ${ }^{9}$

Whatever the strengths or weaknesses of this argument, it has gained a great deal of currency with post-Soviet Georgian scholars as it chimes with the new found confidence of the Georgian Orthodox Church, which claims to be the ultimate arbiter of what constitutes 'authentic' Georgian identity. The idea of the (As)Syrian Fathers being ethnic Georgians 'returning' to their homeland has been most forcefully put forward by Goiladze ${ }^{10}$ but has been comprehensively refuted by scholars such as Matitashvili. ${ }^{11}$ In response to the assertions by Goiladze that Georgians and 'related tribes' had settled in north Mesopotamia and along its rivers, Matitashvili argues that:

The author [Goiladze] believes that the Assyrian Fathers, who were Georgians by their mentality, moved towards Georgia from Edessa, but we cannot agree with this. Here again we have a case of the wrong interpretation of the source. Not one work on the lives of the Assyrian Fathers, nor any other medieval narratives or epigraphical sources mention the Georgian origins of the Syrian Fathers (or that they were monophysites, however V. Goiladze believes that they were dyophysites) in the slightest reference to their origins, but the researchers frequently draw attention to the appeal of their own interpretation and how the sources prove their ideas, which are explained in a highly subjective manner. Accordingly we must conclude that the Assyrian Fathers who came to Kartli were dyophysite Syrian figures. ${ }^{12}$

9 p. 104, Kekelidze, Korneli, 'Sakitkhi siriel moghvatseta kartulshi'.

10 Goiladze, Vakhtang, Asurel mamata samsshoblo da sakartvelo, 2002. This is a self-published booklet.

11 Matitashvili, Shota, 'Kartuli bermonazvnoba VI-VIII saukuneebshi: Sirieli Mamebi', Sami Saunje 2 (2012), pp. 216-23o.

12 pp. 226-227, Matitashvili, Shota, 'Kartuli bermonazvnoba vi-viII saukuneebshi', transla-

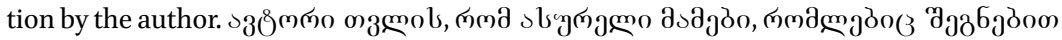

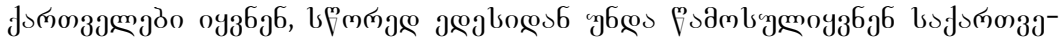

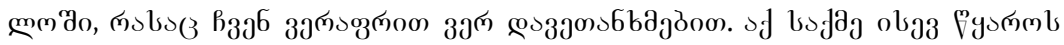
১๓ூ

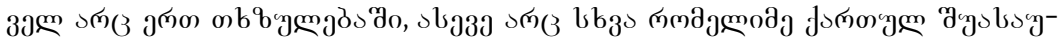

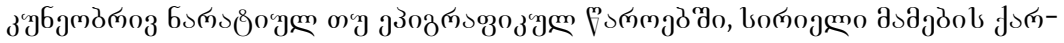

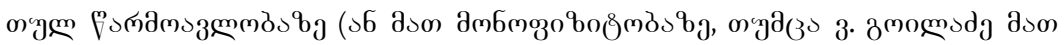

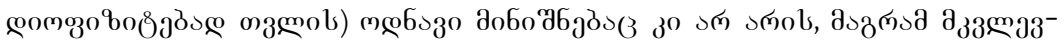


It must be noted that whilst Matitashvili makes his argument based on the evidence from the Georgian sources, his refutation of the presence of Georgian colonies in Mesopotamia is also supported by the fact that no archaeological evidence has yet been discovered to suggest a Georgian presence on Syrian or Mesopotamian territories except for the Georgian monasteries founded in the region around Antioch, largely between the eighth and tenth centuries. In addition we have a great deal of literary evidence from Edessa throughout this period, but there are no references yet studied that refer to a Georgian colony in the city in late antiquity. Bearing this in mind, Matitashvili's argument that Goiladze has interpreted information in an exceptionally subjective manner to reach his conclusions is fully justified, even if his own argument that the (As)Syrian Fathers were in fact dyophysite Syrians remains a matter for debate.

Whilst this is a question that is destined to continue in Georgian historical literature, and will be the focus of increasing research as ecclesiastical history develops further as a sub-discipline of post-Soviet Georgian historical studies, the time has come to reconcile the fact that the only literary evidence we have for these figures comes from the Georgian side and, as accepted by all participants in the debate, these accounts were all written some years after the events that they purport to recount. However, medieval literature is not to be dismissed so lightly as completely inaccurate as it often yields a great deal of valuable information. The difficulty is separating the useful information from later accretions or falsifications that have been added for political or doctrinal factors and it is to this task that we shall now turn.

\section{What's in a Name? Can We Use the Names of the (As)Syrian Fathers as Any Indication of Their Ethnic or Denominational Origins? Part One: Toponyms}

One of the first things that anyone interested in the question of the (As)Syrian Fathers in Georgia will encounter is their seemingly exotic sounding names. At first hearing designations such as Davit Garejeli or Ioane Zedazneli would appear to offer more information than usual as most saints are known by one name alone, and it is only in the recent past that family names have become

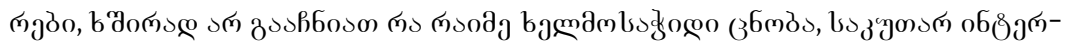
उल

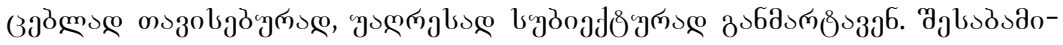

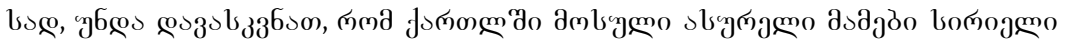

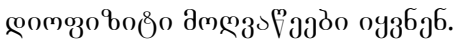


a common occurrence. However in this case the phenomenon is explained by the fact that each of the thirteen (As)Syrian Fathers is assigned a toponym that associates them with a location in Kartli or Kakheti. Therefore we are given the name of the place in Georgia where each father settled or lived for the longest period of time during their life in Kartvelian lands, rather than being offered any information about their origins. It is worth noting that each of these figures is associated primarily with the place that they founded a monastery and that this is in many cases (but not all) synonymous with where they are believed to have been buried. However more than one location within the country may have an association with an individual (As)Syrian Father as some lived in multiple locations or were martyred away from their primary residence.

A case in point is Davit Garejeli, who although not the presumed leader of this group (that role being assigned to Ioane Zedazneli) is nevertheless arguably the most well known of these figures today. We can ascribe this continuing popularity to two factors in particular, both related to questions of geography. The first is that his name is given to the lavra that stands in the Gareja desert ${ }^{13}$ and although this monastery is only the largest and most important of the many foundations that honeycomb the rocks in the region, it is the name by which the whole complex of monasteries and hermitages has become known. The second point is that Davit was the only one of the thirteen (As)Syrian Fathers to be linked to the capital city Tbilisi. This is interesting as the city as we know it today is believed to have been founded in the fifth century CE. Although there is archaeological evidence for a number of ancient settlements on the territory now covered by the extended modern city, ${ }^{14}$ the legend of the foundation of Tbilisi states that the semi-legendary fifth century King Vakhtang Gorgasali was hunting when he discovered hot springs and decided to found a city on the site. 'Tbilisi' is therefore said to come from the word tbili (obogmo) meaning 'warm'. The moving of the capital of Kartli to Tbilisi from the ancient city of Mtskheta approximately $25 \mathrm{~km}$ to the north west occurred at some point in the sixth century and this is what is intriguing about Davit; his story is linked

13 Georgians refer to this semi-arid landscape as the Gareja desert, but it is more accurate to describe it as being steppe land.

14 There has been settlement of the wider region today swallowed up by metropolitan Tbilisi for millennia. For an overview and information on sites from the Chalcolithic until the Classical eras see Abramischwili, Rostom \& Michael, 'Archäologische Denkmäler im Stadtgebiet von Tbilissi' in Miron, Andrei \& Orthmann, Winfried (eds.), Unterwegs zum Goldenen Vlies. Archäologische Funde aus Georgien, Museum für Vor- und Frühgeschichte Saarbrücken; Saarbrücken, 1995, pp. 185-205. 
closely to this new city whereas Ioane Zedazneli and the core of the fathers are associated with sites in the area directly around the ancient capital; Mtskheta.

The fact that according to medieval Georgian chronicles it was in the reign of the Kartvelian King Dachi, son of Vakhtang Gorgasali, that the capital was officially moved from Mtskheta to Kartli places this event in the early sixth century. Thus the chronicles locate the advent of the new capital and the arrival of the (As)Syrian Fathers within a few years of each other. Read in this light one can posit that whilst the leader of the group Ioane Zedazneli and his closest disciples headed for the old seat of power that retained influence as the ecclesiastical centre of the country, Davit made the decision to inhabit a cave on the hillside above Tbilisi. Although the tradition is that Davit was at pains to underline his desire for solitude ${ }^{15}$ the reader is perhaps justified in remaining sceptical of these claims given that his chosen refuge was less than an hour's walk from the city of Tbilisi. When a woman claimed that he was the father of her unborn child, he called upon God to support him by stating that she would give birth to a stone. When events transpired as he had predicted at the spot now occupied by Kashveti church on Rustaveli Avenue in Tbilisi (the church is named for this event), he left the capital for the 'desert' of Gareja.

These events are recounted here because it is perhaps because of this biography that Davit Gareja remains arguably the most famous of the thirteen Fathers today. The monastic complex at Gareja is the largest in the country and there are two sites associated with Davit in Tbilisi, Kashveti being placed directly opposite the old parliament building of the country, thus assuring him of a prominent place in the history of the country. Whereas the vitae of many of the other fathers are not as well known, it is interesting to note that many of them are like Davit in being associated with several locations within Kartli and Kakheti. For example Abibos Nekreseli is primarily associated with the monastery of Nekresi in Kakheti and yet his tenth century vita reports that he visited the grave of his fellow father, Shio, at Shiomghvime monastery near Mtskheta before finally being martyred at Rekha. Similar tales of monks moving across the landscape are associated with several of the lesser known fathers, but whilst helping us to build up a picture of the spread of monasticism across Kartli and Kakheti this data still fails to help us understand the origins of these figures.

15 The vita of Davit can be found in the original Georgian in Abuladze, Ilia, Dzveli kartuli agiograpiuli literaturis dzeglebi, 6 vols., Gamomtsemloba 'Metsniereba'; Tbilisi, 1963-1989 and in translation in Lang, David Marshall, Lives and Legends of the Georgian Saints, Mowbrays; London \& Oxford, 1976 but this does not give an account of Davit's life in the environs of Tbilisi. 
Some of the fathers have references to their origins in their (always much later) vitae. In this way it is suggested that Ioane Zedazneli came from Syria or Mesopotamia as he travelled to Kartli via the environs of Antioch where he sought the blessings of Symeon Stylites the Younger. More specifically Ioane is referred to in the vita of Davit Garejeli as originating 'from the borders of Antioch in the land of Mesopotamia."16 If this means the city of Antioch-inMesopotamia then Ioane must have originated from the region of Viranşehir in southeast Turkey, which is believed to have been built within the area of the older city named Antioch. Similarly Davit Garejeli is referred to as coming from 'the Mesopotamian valley of Assyria.'17

However, as mentioned above, these vitae were written several centuries after the events that they purport to recount and the more removed they were from the sixth century, the more embroidered the accounts became. This is a question discussed by Aleksidze in his consideration of how the story of the mandylion of Edessa became part of the narrative of the (As)Syrian Fathers. Aleksidze discusses how the oldest (1oth century) text referring to the fathers does not include Anton Martqopeli in the list of names despite the belief in contemporary Georgia that he brought the mandylion to Kartli. ${ }^{18}$ In answer to a question raised by other historians including Kekelidze, Aleksidze considers why the numbers and names of these figures are not consistently the same in all the sources and why some now prominent figures such as Anton Martqopeli are not mentioned in the earliest recensions of the texts. Although traditionally they are referred to as the Thirteen Fathers, a figure with obvious New Testament resonance, some lists have fifteen or sixteen names and the variant lists do not always reconcile with each other. Aleksidze persuasively suggests that some names on the later lists could have been Kartvelian disciples of the original monks who were so devoted and ascetic in their way of life that they were ultimately added to the list of the (As)Syrian Fathers-for example Dodo Garejeli, a disciple of Davit Garejeli would be one of the most prominent figures in this category.

If we accept Aleksidze's logical argument for how the layers of later interpretation were added to the vitae to explain Kartvelian beliefs about the mandylion and its equally miraculous offspring, the keramidion, then it becomes clear how much later accounts are at pains to present a strong relationship between Kartli

16 p. 83, Lang, David Marshall, Lives and Legends of the Georgian Saints, Mowbrays; London \& Oxford, 1976.

17 p. 83, Lang, David Marshall, Lives and Legends of the Georgian Saints.

18 p. 13, Aleksidze, Zaza, 'Mandilioni da keramioni dzvel kartul mtserlobashi', Academia 1 (2001), pp. 9-15. 
and Edessa to account for why and how these relics arrived in the country. Aleksidze identifies the keramidion of Hierapolis with Ezderios/Isidore Nabukeli, who was later named Samtavneli, and who bought the relic to Kartli serving as the 'censer and servant' of the keramidion. ${ }^{19}$ In the same way the 'Icon of Edessa' (mandylion) was later translated to Kartli by Theodosius/Tadeoz/Tata of Urhai (Edessa) who became known as Theodosius Rekhali or Stepantsmindeli in later lists of the (As)Syrian Fathers. The fact that stories of Anton Martqopeli bringing the keramidion or mandylion to Kartli started circulating much later than the accounts of Ezderios and Theodosius is used by Aleksidze to underline his point that these stories shifted over time, and establishing the exact number and identity of the monks who are believed to have travelled to Kartli and Kakheti in the sixth century remains a complex and time consuming process.

\section{What's in a Name? Part Two: Christian Names}

Often in academia it is easy to get carried away by arcane details and overlook simple points. One element of the story of the (As)Syrian Fathers that particularly bears this out is the lack of consideration of the given names of these figures. As the preceding section highlighted, there has been a certain amount of debate around the toponyms associated with these fathers and this has been helpful in allowing us to draw a monastic map of Kartli and Kakheti based upon the locations where these monks are believed to have lived, served and died. However it is an undeniable fact that the given name of a person is often an indicator of their ethnic origin or betrays the fact that their parents wanted to curry favour with a regional power or influential patron. ${ }^{20}$

One of the most well known examples of this phenomenon in Georgia is the case of the silver dish in the treasury of the Simon Janashia State Museum in Tbilisi. The dish is inscribed in Greek as being a gift from Basileus Flavius Dad to Pitiakhsh Bersouma and although it was discovered in a third century CE grave, Gagoshidze and Margishvili have demonstrated that the artefact was originally made in the first century $\mathrm{CE}^{21}{ }^{21}$ They also highlight that this inscription perfectly encapsulates the political situation in first century Kartli. The

19 p. 13, Aleksidze, Zaza, 'Mandilioni da keramioni'.

20 This of course refers to a variety of historical contexts. It is not an argument that can be employed in the twenty first century where the interconnected world of social media means that names alone are now not a reliable measure of identifying ethnicity.

21 Gagoshidze, Iulon \& Margishvili, Soso, 'Mepe Plavius Dedes Vinaobistvis', Iberia-Colchis 9 (2013), pp. 68-87. 
grave it was found in was located in the necropolis at Armaziskhevi, Mtskheta, for pitiakhshes. This was a title given to the Persian viceroys who served alongside the Kartvelian rulers in the first centuries CE to underline Persian power in the region. Therefore we have an inscription where a local sovereign is using the Greek title designating a king in the Graeco-Roman world, Basileus, with a hybrid Romano-Persian given name as Flavius was presumably chosen due to the fact that it was the family name of Vespasian and his sons, and Dad is a well-attested Iranian name. ${ }^{22}$ Therefore the giver of the gift was presumably of Kartvelian origin, but had adopted a Roman title and hybrid Romano-Persian name to appease the empires that were seeking to control Kartvelian territory in this period. In the case of the recipient of the gift, Pitiakhsh Bersouma, whilst his role as pitiakhsh is clearly understood, nobody has yet commented on the fact of his name. Bersouma is a popular Syrian and Assyrian Christian name to this day and therefore it is clear that the holder of the office of pitiahksh at this time came from a Syriac-speaking background. Given the territorial boundaries of the period and the fact that this man was serving the Persian empire this is most likely to place him as originating in the land that we today call Iraq or alternatively from part of south eastern Turkey or north western Iran. What remains clear is that Bersouma is a name that is associated entirely with Syriacspeaking people and in the first century CE their lands were divided, as were the Kartvelian lands, between the Roman and Persian Empires. In this case there was no material gain to be had by adopting a Syriac name and therefore it seems almost certain that Bersouma was an ethnic Assyrian who had been promoted for loyal service to the Persian Empire.

The above digression is necessary because when discussing the (As)Syrian Fathers one would expect to find names such as Bersouma amongst the list. However this is far from being the case as no single name can be taken as being typically Syrian (or Assyrian) in origin. On the other hand many names are relatively neutral ones that were common to many Christian cultures in late antiquity, some are typically Greek in origin and others are not recognisable as coming from any of the local cultures. If we take the thirteen names most commonly listed as comprising the (As)Syrian Fathers today ${ }^{23}$ we can see that it is in fact extremely difficult to link these names definitively to Syrian society.

22 See p. 241 of Iberia-Colchis 9 for an English summary of the above paper where the etymology of this name is discussed.

23 The inclusion of names like Anton Martqopeli means that this list is, as Aleksidze has argued, heavily altered from the earliest sources. However the list does include the most significant figures and those who are still most revered by the contemporary Georgian Orthodox Church. 
TABLE 1 List of the names of the Thirteen (As)Syrian Fathers as accepted in contemporary Georgian tradition and their possible Syriac and Greek cognates

Name

\section{Syriac equivalent}

Abibos Nekreseli ${ }^{24}$

Anton Martqopeli

Davit Garejeli

Ioane Zedazneli

Ioseb Alaverdeli

Ise Tsilkneli

Isidore/Ezderios Samtavneli

Mikael Ulumboeli

Piros Breteli

Shio Mghvime

Stepane Khirseli

Theodosius/Tadeoz/Tata

Rekhali/Stepantsmindeli

Zenon Ikaltoeli
Antoun

Daoud

Yohannon

Yusuf

Isa, Yeshua

Isidore $^{25}$

Mikael

Estapanos

Theodosius ${ }^{26 / A d d a i ~ T h e o d o s i u s ~}$
Greek equivalent

Antonios

David

Ioannnes

Iosif

Isidore

Michail

Pyrrhus

Stefanos

Unknown

origin

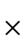


as being (As)Syrian in origin, but does weaken the case in so far as one would expect there to have been more regionally specific names such as Bersouma, Ephrem/Afram or Abo to have been present on the list. This is especially the case considering that the patron saint of Tbilisi, St. Abo is an eighth century martyr of Christian Arab origins with a name that clearly identifies him as originating from a Syriac or Arabic speaking milieu. Therefore we are forced to question why it is that none of these figures has a definitively Syriac name; is this because the later written accounts did not know the names of these monks and so chose suitable sounding appellations? Or is it because they were not actually (As)Syrian at all? Alternatively we must ask if the confusion is because they simply did not exist, or at least not in the way that later accounts portray.

\section{Evidence for Syriac Epigraphy on Kartvelian Territory: Myths and Rumours}

As discussed in chapter three, although in conversation with Georgian archaeologists and art historians 'Syrian' objects were often referred to, when these beliefs and assumptions were examined more closely the evidence was almost entirely non-existent and amounted only to quantities of Syrian-made glass and Roman era coins, with the coins being found almost without exception in the west of the country in Lazica/Egrisi rather than in Kartli and Kakheti, the regions associated with the (As)Syrian Fathers. This lack of Syrian provenanced items also extended to a lack of Syriac in the sense that there have been no Syriac inscriptions discovered on Georgian territory at the time of writing. Where an item had been catalogued as being inscribed with Syriac, further investigation proved that the writing was early Arabic and an ornamental motif respectively. ${ }^{27}$ Given the lack of Syriac evidence it is interesting to note that there is a great deal of evidence of early Arabic epigraphy across Kartli with examples as diverse as an inscription incorporated in the city walls of Tbilisi ${ }^{28}$ and the medieval gravestones at Dmanisi. Bearing this in mind it is especially intriguing that several historians have made reference to Syriac inscriptions appearing on early frescoes in Kartli; given that these paintings are long destroyed, is it possible to draw any conclusions from these tales of Syriac epigraphy?

\footnotetext{
27 See chapter 3.

28 Giorgi Gagoshidze, National Agency for Cultural Heritage Preservation of Georgia, pers. comm.
} 
The specific instances under discussion relate to Samtavisi and Rekha and the stories of Ezderios/Isidore and Theodosius/Tadeoz. As Aleksidze has demonstrated in his research into the oldest recensions of the vitae of the (As)Syrian Fathers based upon his work with the Georgian corpus of manuscripts from St. Catherine's monastery in Sinai, ${ }^{29}$ the earliest extant accounts of these fathers dates to the tenth century and this appears to be accepted as the period when these accounts were first written, although Kekelidze argues that some of the vitae, in particular that of Abibos Nekreseli, date to the ninth century. ${ }^{30}$ However it must be noted that Aleksidze's discovery of the Sinai recensions is currently reshaping our considerations around the historiography of the (As)Syrian Fathers and a definitive view on the dating of these texts awaits the final publication of a critical edition of the Sinai texts.

Leaving these issues aside, what we are left with is what the common consensus suggests as tenth century texts referring to events that purport to have taken place in the sixth century and, most commentators agree, in the first half of that century-therefore during the reign of the Byzantine Emperor Justinian. This point is crucial as we know that it was a turning point in the postChalcedonian Christological debate and is now widely accepted as the period when the positions of the opposing sides crystallised. ${ }^{31}$ With these events as the backdrop it is necessary to understand that, as Kekelidze rightly pointed out, the later historiographical tradition was likely to reflect the tenth century stance of the Kartvelian writers of the vitae, who were avowedly dyophysite and pro-Constantinopolitan in doctrinal terms.

So what is the claim regarding Syriac inscriptions in sixth century Kartli? Once again these references to the use of Syriac are related to the Georgian traditions surrounding the mandylion and the keramidion. Karaulashvili has written extensively on the Georgian literary tradition relating to these artefacts $^{32}$ and the comparative literature relating to King Abgar and the mandylion

29 Aleksidzé, Z. (Introduction), Trans. Mahé, J.-P., Le nouveau manuscript géorgien sinaïtique N Sin 5o, Corpus Scriptorum Christianorum Orientalium, Vol. 586, Subsidia 108, Louvain, 2001.

$30 \quad$ p. 84 , Kekelidze, Korneli, 'Sakitkhi siriel moghvatseta kartulshi'.

31 For more on this process see Menze, Volker L., Justinian and the Making of the Syrian Orthodox Church, Oxford University Press; Oxford, 2008.

32 Karaulashvili, Irma, 'The date of the Epistula Abgari', Apocrypha 13 (2002), pp. 85-111, 'Anchiskhati: keramidioni hierapolisdan tu mandilioni edesidan?', Mravaltavi 20 (2003), pp. 170-178, 'The Abgar Legend Illustrated: The Interrelationship of the Narrative Cycles and Iconography in the Byzantine, Georgian and Latin Traditions' in Hourihane, Colum (ed.), Artistic Interchange between the Eastern and Western Worlds in the Medieval Period, 
in other languages and she points out that whereas the initial accounts of the 'Image of Edessa' can be dated to the sixth century, it is only later that visual representations of this relic begin to appear. Whilst technical analysis of the most famous image of the Edessene type in Georgia, the Anchiskhati Icon, has proved the original is a sixth century encaustic icon ${ }^{33}$ it is also on record that this image only entered modern Georgian territory in the seventeenth century after Ancha, which was formerly Georgian land, fell to the Ottoman Turks. Therefore we must look elsewhere for visual evidence of when images of this type first appeared in Kartli and here we are dealing with two separate categories; those images that are still extant and those that are lost and that are only known through literary references to them.

Karaulashvili reports that the first recorded image of the mandylion in a Georgian manuscript is in the Alaverdi Four Gospels of 1054, now housed in the National Centre of Manuscripts in Tbilisi ${ }^{34}$ and that there are two cases of early fresco paintings with the image in Kartli. The first is in the seventh century Church of the Ascension of the Saviour in Tsromi ${ }^{35}$ which was identified as having a mandylion image by a variety of early and mid-twentieth century art historians but that has since been disputed by Zaza Skhirtladze, who has reattributed this scene as 'Christ in Majesty' or the Ascension of Christ. Despite this debate, Karaulashvili prefers to include this image as an early mandylion until definitively proved otherwise. The other fresco is at the Church of the Holy Cross in Telovani not far from Samtavisi, which is a site that we shall turn to in a moment. Karaulashvili accepts Skhirtladze's dating of the cycle in this church to two periods; an earlier phase of the eighth to ninth century and a later one of the tenth century and points out that this is the earliest example of the 'Image of Edessa' still extant in Georgian territory. Therefore, and this is maybe no coincidence, the earliest uncontested images of this type appear in Georgia at the same time as the texts recording the vitae of the (As)Syrian Fathers were being composed.

Pennsylvania State University Press; Pennsylvania, 2007, pp. 220-243, 'A Short Overview of the Nationalised Peculiarites of the Abgar Legend in Georgian, Armenian and Slavonic traditions', Scripta 10-11 (2012), pp. 171-184, 'Abgar Legend: Text and Iconography', Kadmos 6 (2014), pp. 164-240.

33 Pers. comm. Elene Kavlelashvili, Chief Curator of the Treasury of the Shalva Amiranashvili Art Museum, Tbilisi.

34 p. 173, Karaulashvili, Irma, 'Abgar Legend: Text and Iconography', Kadmos 6 (2014), pp. 164240 .

35 p. 169 ff., Karaulashvili, Irma, 'Abgar Legend: Text and Iconography'. See also http://architectureandasceticism.exeter.ac.uk/items/show/118 for exterior images of this church as it looks now. 
After this long, but necessary, preamble we now turn to the question of Syriac inscriptions. In his work on the vitae of Theodosius/Tadeoz of Urhai (later Rekhali/Stepantsmindeli) and Isidore/Ezderios Nabukeli (later Samtavneli) Aleksidze has found references to both building new churches at Rekha and Samtavisi respectively, and both also commissioning images of the Saviour to be painted in these new churches in a manner that resembled the icons not made by human hands, that is the acheiropoietos icons of the mandylion and the keramidion. ${ }^{36}$ According to the hagiographical evidence the churches of Samtavisi and Rekha were built in the sixth century and were still extant at the time that the vitae were written in the tenth century. Today the church at Rekha has been lost but beside the thirteenth century church at Samtavisi archaeologists have excavated the remains of a fifth century basilica with walls that survive to approximately knee-height, the rest of the stone presumably having been mined for the construction of the medieval cathedral directly to the north of the earlier building. Naturally these circumstances mean that no traces of fresco survive at either site.

Aleksidze emphasises this tradition of two sixth century images of the Saviour because he is at pains to emphasise that this account is significantly earlier than the story of Anton Martqopeli and the keramidion or mandylion and therefore represents an earlier stratum of the mandylion story in Georgia. Aleksidze recounts that the sources refer to the 'icons' as 'miraculously showing the Saviour painted by angels. ${ }^{37}$ However in the case of the Rekha fresco the image deviated from the standard mandylion representation of Christ's face or his bust by having his entire body depicted. In addition Aleksidze reports that this fresco had an inscription 'in the Syrian language' at the feet of the Saviour saying 'Who you see here, He has sent me. ${ }^{38} \mathrm{He}$ then uses this account to argue that this piece of evidence is one of the reasons why the argument that the (As)Syrian Fathers were ethnically Kartvelian is incorrect.

Karaulashvili refers to this account by Aleksidze in her work on the legends surrounding King Abgar and the mandylion in the Georgian tradition but the reference to Syriac inscriptions on early Georgian frescoes has not been referred to in any other sources and therefore we rely simply on this account in the vitae of Theodosius/Tadeoz and Isidore/Ezderios to offer any reference at all to a Syriac inscription on Kartvelian territory. Once again we are in a situation where we are relying on tenth century testimony to tell us of the events

\footnotetext{
36 p. 13, Aleksidze, Zaza, 'Mandilioni da keramioni'.

37 ibid.

38 ibid.
} 
of four centuries earlier. All we can say is that we know that there was a basilica built in Samtavisi around this time and that there are ruins in the vicinty of Rekha that could be the other church if the money and time were available to excavate the area. Whether or not these buildings had frescoes is impossible to answer, although we can accept this as a plausible scenario. On the other hand what can we make of these references to inscriptions in the 'Syrian language'? Is this really any more reliable than the conflicting accounts of which languages the (As)Syrian Fathers spoke when interacting with the local populace? Was this tradition handed down faithfully over the centuries or did a scribe add it in to the vitae in an attempt to lend credence to the claim that these men originated in (As)Syria? Obviously it is impossible to know the answers to these questions but what is clear is that this is yet another case where the 'evidence' has not yielded concrete support for the argument that these men were Syrian or Assyrian monks.

\section{Timeline of a Tradition: Matching the Sources to the Monuments}

Whilst it might be tempting to dismiss the vitae as later inventions this would be a major error. It is clear that the sites linked with these figures are largely locations that played a significant role in the development of Kartvelian Christianity and the majority of the locations have buildings or archaeological evidence that confirms a Christian presence back to the fifth or sixth century CE. If this fact is considered with the argument put forward by Kekelidze that the (As)Syrian Fathers did not all arrive at the same time, but instead appeared in 'waves' throughout the early to mid sixth century ${ }^{39}$ then we could be looking at a scenario where groups of foreign monks travelled to Kartli and Kakheti in late antiquity looking to found ascetic institutions and these (As)Syrian Fathers are a cultural memory of that event. Tamila Mgaloblishvili ${ }^{40}$ argues that the thesis put forward by Kekelidze has some validity, but suggests that it can be pushed further. She points out that whilst his argument that these figures arrived singly or in groups over several decades in the early sixth century is very convincing, she sees no reason as to why it must be assumed that all thirteen (or fifteen or sixteen or however many there were in all) were of the same doctrinal persuasion. Given the confused circumstances of the time and the fact that Kartli and Kakheti stood at the crossroads with dyophysite Byzantines to the west,

39 Kekelidze, Korneli, 'Sakitkhi siriel moghvatseta kartulshi'.

40 pers. comm. Tamila Mgaloblishvili. 
miaphysite Armenians to the south and Assyrians who rejected the concept of the Theotokos to the east, then there is no reason to believe that all these men came from the same doctrinal standpoint; in actual fact it seems logical to consider the possibility that they were refugees from more than one direction who, by extension would have spoken varied languages, had different ethnic origins and espoused contradictory doctrinal arguments.

If this is taken as our starting point then the pieces of the puzzle shift and we can see a picture beginning to emerge. The places associated with these figures are, as mentioned above, largely confirmed as having initially had churches built in the fifth or sixth century. This is a period when church hierarchies and doctrine are becoming increasingly rigid and monasticism is moving away from more unregulated eremitical practices towards communal life governed by rules and regulations. Here we have new institutions being established that offer a religious experience to pious men and which lay the foundations of Kartvelian monasticism. When this pivotal age of ecclesiastical history is later recorded by medieval chroniclers it could be argued that the messy reality of a mosaic of doctrines and ethnicities is smoothed away as a more polished view of the situation is developed. Here the biblical resonance of thirteen holy men arriving to spread the good news offers a more elegant version of reality and, given that the Georgian Church had been dyophysite since the early seventh century, a gloss is given to imply the 'orthodoxy' of these holy men in order to retrospectively cleanse the Kartvelian historical narrative.

\section{Reconciling the Literary Texts with the Evidence from Material Culture}

If the scenario above is accepted it suggests that whilst foreign ascetics did flee to the wilds of Kartli and Kakheti in the sixth century, they may have travelled there for a variety of different motives from a series of different countries; it is only later on that chroniclers decided to create the narrative of the thirteen (As)Syrian Fathers when they sought to write the ecclesiastical history of their country. This argument follows a middle way in that it does not deny the existence of a group of travelling ascetics in late antique Kartli and Kakheti, but it does not accept that there were thirteen or that they were necessarily Syrian or Assyrian.

However when we take the evidence produced by material culture into account a slightly different picture begins to emerge. Here the lack of textual sources is accompanied by the corresponding lack of artefactual and architectural evidence discussed in previous chapters to point in a slightly more 
nuanced direction. In this case the evidence is solely of a relationship with territories where Assyrian rather than Syrian Christians were present. This evidence suggests a cultural and economic exchange with the Persian Empire including Mesopotamia, the homeland of people descended from the Assyrians, but as analysed previously there is a surprising lack of evidence from Syria. Therefore this narrows the possible origins of our visitors even further and suggests that they came most probably from the Persian-controlled areas of Mesopotamia. This in turn has implications for the doctrinal identity of these figures. We know that there were miaphysites in the region, with a larger Assyrian (the group pejoratively labelled 'Nestorian') community, but no Chalcedonian Christians. Therefore the ideas advanced by Mgaloblishvili regarding different groups and confessions seem entirely correct with several caveats; firstly ethnically they are likely all to have been of Assyrian origin, although whether they themselves self-identified in this way is open to debate. ${ }^{41}$ Secondly they were probably both miaphysite and Assyrian in their confessional identity, but not Chalcedonian. This swings the evidence in favour of declaring with some degree of certainty that these missionaries were Assyrian rather than Syrian and that this was almost certainly linked to the thus far unexplained disruption in relations between the east and west of Georgia, where the west looked towards Constantinpole and Antioch for trade, religious and political affairs whilst the east looked to their overlords, the Sassanian Shahs of Persia.

With all locations associated with the (As)Syrian Fathers being located in Kartli and Kakheti this was a wholly eastern phenomenon that took place independently of events in the western-facing, more Chalcedonian orientated territory of Lazica/Egrisi. It was not until the late sixth century and the events that led to the break with the Armenians at the Third Council of Dvin in 6o9-61o that these western elements politically and doctrinally permeated the east. Of course the quest for material evidence for this change is somewhat complicated by the fact that the region was invaded by the Arabs shortly thereafter, but what the Arab invasion places in sharp juxtaposition with the earlier period is just how little contact there had been with Arab lands in the centuries immediately before the advent of Islam.

41 Richard E. Payne, 'Avoiding Ethnicity: Uses of the Ancient Past in Late Sasanian Northern Mesopotamia' in Pohl, Walter, Gantner, Clemens \& Payne, Richard E. (eds.), Visions of community in the post-Roman world the West, Byzantium and the Islamic world, 300-1100, Ashgate: Farnham \& Burlington, VT, 2012, pp. 205-221. 